\author{
EDWARD OPALIŃSKI* \\ ORCID: 0000-0003-3962-7495
}

\title{
KONWOKACJA SENATU W 1608 ROKU $^{1}$
}

\section{Convocation of the senate in 1608}

Abstract

After the completion of the sedition convention near Warsaw in mid-October 1607, many months of efforts to pacify the country began. Both the rebels and the regalists were striving for this, and both sides tried to impose their own conditions. The leader of the sedition, Mikołaj Zebrzydowski, wanted the reconciliation to take place at a convocation of the Senate, where the monarch was to be absent. Therefore, he aimed to diminish the authority of Sigismund III. The king, supported by the Senate, forced the rebel to apologize to him in front of the Senate's convocation. Zebrzydowski eventually agreed but made the monarch and the Senate wait more than 40 days for his appearance.

Keywords: Convocation, sedition, Senators, Sigismund, Zebrzydowski

\begin{abstract}
Abstrakt
Po zakończeniu w połowie października 1607 roku zjazdu rokoszowego pod Warszawą, rozpoczęły się wielomiesięczne zabiegi o doprowadzenie do pacyfikacji kraju. Dążyli do tego tak rokoszanie jak i regaliści, jednak obie strony starały się narzucić własne warunki. Przywódca rokoszu Mikołaj Zebrzydowski chciał, aby pojednanie odbyło się na konwokacji senatu, na której miało nie być monarchy. Dążył więc do pomniejszenia autorytetu Zygmunta III. Król poparty przez senat wymusił na rokoszaninie przeprosiny własnej osoby przed konwokacją senatu. Zebrzydowski wyraził ostatecznie zgodę, ale kazał monarsze i senatowi czekać na swoje pojawienie się przeszło 40 dni.
\end{abstract}

Słowa kluczowe: konwokacja, senatorowie, rokosz, Zebrzydowski, Zygmunt

\footnotetext{
* Profesor dr hab. Edward Opaliński, zajmuje się historią parlamentaryzmu i kulturą polityczną. Zatrudniony w Instytucie Historii PAN oraz na Uniwersytecie Jana Kochanowskiego (filia w Piotrkowie Trybunalskim). E-mail: e.opalinski@gmail.com.

1 Publikacja powstała w wyniku realizacji projektu badawczego o nr 2017/27/B/HS3/02648 finansowanego ze środków Narodowego Centrum Nauki.
} 
Konwokacje senatu nie były instytucjami parlamentarnymi, choć składały się wyłącznie z członków izby wyższej polsko-litewskiego sejmu lub, w czasach przed 1569, polskiego parlamentu. W polityce ostatnich Jagiellonów, a także Stefana Batorego, konwokacje senatu miały umożliwić sprawowanie władzy bez konieczności odwoływania się do parlamentu. Jak stwierdza Ewa Dubas-Urwanowicz, analizując panowanie Stefana Batorego, „Od początku swych rządów król uruchamia rzadko stosowaną za panowania jego poprzedników i źle widzianą przez szlachtę instytucję w funkcjonowaniu państwa - konwokację senatu"2. Z kolei Leszek Kieniewicz podkreśla, że specjalnie zwoływane konwokacje senatu nie były przewidywane przez prawo koronne ${ }^{3}$. Historycy nie są zgodni w określeniu, czym były konwokacje senatu. Izabela Lewandowska-Malec stwierdza, że Zygmunt III zwoływał konwokacje senatu między sejmami, a najczęściej po każdym bezowocnym sejmie ${ }^{4}$. Podobne zdanie prezentuje Jan Rzońca, który pisze, że w dzień po bezowocnym zakończeniu sejmu, czyli 26 marca 1597 r., król zwołał tajną naradę senatu ${ }^{5}$. Inaczej na tę kwestię zapatruje się E. Dubas-Urwanowicz, nie uznająca za konwokację narady senatu z królem po zakończeniu sejmu koronacyjnego (od 12 czerwca do 10 lipca 1576), która z kolei jest za takową uważana przez Leszka Kieniewicza ${ }^{6}$. Nie wdając się w tym miejscu w spory historyków, autor chce podkreślić, że za konwokację senatu uważa, podobnie jak E. Dubas-Urwanowicz, naradę całego senatu z królem, zwołaną przez monarchę w okresie między sejmami. Natomiast posiedzenia senatu odbywające się bezpośrednio po zakończonym sejmie, bezowocnym lub owocnym, określa jako rady senatu. Tak definiowaną konwokacją senatu Zygmunt III Waza posługiwał się dużo skromniej niż jego poprzednicy. W latach 1587-1608 użył tej instytucji zaledwie kilkakrotnie. Po raz pierwszy w 1588 roku w dniach 14-18 października. Po raz drugi, wg Adama Strzeleckiego, po sejmie 1603 roku, który odbył się w Krakowie. Zwołano ją do Łobzowa, a monarcha w trakcie jej posiedzenia deklarował, że nie myśli o ożenku z Konstancją Habsburżanką. Po raz trzeci Zygmunt III wezwał do siebie senat w 1606 roku. Była to reakcja na decyzję zjazdu lubelskiego o zwołaniu zjazdu rokoszowego do Sandomierza na 6 sierpnia. Jarema Maciszewski, pisząc lakonicznie o tej konwokacji, stwierdza, że król zwołał ją na 30 lipca do Krakowa, w innym jednak miejscu twierdzi, że zjazd senatorów miał mieć początek 28 lipca $^{8}$. Niestety weryfikacja tych rozbieżności jest utrudniona, ponieważ różne kopie uniwersału królewskiego podają odmienne daty rozpoczęcia konwokacji ${ }^{9}$. Niemniej jednak pierwszy historyk rokoszu, a więc Stanisław Łubieński, nie ma wątpliwości i datuje początek konwokacji na 30 lipca $^{10}$. O przebiegu konwokacji

\footnotetext{
2 E. Dubas-Urwanowicz, O nowy ksztalt Rzeczypospolitej. Kryzys polityczny w państwie w latach 1576-1586, Warszawa 2013, s. 33.

3 L. Kieniewicz, Senat za Stefana Batorego, Warszawa 2000, s. 144.

4 I. Lewandowska-Malec, Vicarius regis. Rola arcybiskupa gnieźnieńskiego pod nieobecność króla elekcyjnego, w: Krakowskie studia z historii państwa i prawa, t. 3, red. W. Uruszczak, D. Malec, M. Mikuła, Kraków 2010, s. 94.

5 J. Rzońca, Sejmy z lat 1597 i 1598. Część I. Bezowocny sejm z 1597 roku, Warszawa-Wrocław 1989, s. 114.

E. Dubas-Urwanowicz, op. cit., s. 34; L. Kieniewicz, op. cit., s. 144-145.

A. Strzelecki, Sejm z roku 1605, Kraków 1921, s. 10.

J. Maciszewski, Wojna domowa w Polsce (1606-1609). Część I. Od Stężycy do Janowca, Wrocław 1960, s. 205 i 211 .

B. Czart. 339, k. 169v - 26 VII; B. Racz. 18, k. 216v -26 VII; B. Czart. 341, s. 237 - 30 VII.

10 S. Łubieński, Droga do Szwecji Zygmunta III, króla polskiego i szwedzkiego, w 1593 roku, Rozruchy domowe w Polsce w latach 1606-1608, wyd. J. Byliński, W. Kaczorowski, Opole 2009, s. 86.
} 
niewiele wiadomo, poza tym, że ustalono na niej zwołanie przez Zygmunta III zjazdu całej szlachty i senatorów do Wiślicy.

Pomysł, żeby senatorowie doprowadzili do uspokojenia Rzeczypospolitej wyszedł od Janusza Radziwiłła, który kierował zjazdem niedobitków rokoszańskich zgromadzonych w Lublinie. Informuje o tej inicjatywie Janusz Ostrogski, kasztelan krakowski, w liście z 20 lipca 1607 do hetmana polnego koronnego i kasztelana lwowskiego Stanisława Żółkiewskiego ${ }^{11}$. Na przełomie września i października Zygmunt III przedstawił „Sposoby do przyjęcia w łaskę Pana Wojewody Krakowskiego". W liście z 4 października 1607 skierowanym do senatorów monarcha informował adresatów o swej inicjatywie i prosił o opinię ${ }^{12}$. W jednym z punktów król domagał się, aby M. Zebrzydowski w czasie wskazanym przybył w niewielkim orszaku i oficjalnie go przeprosił. W innym zobowiązano go, aby w przyszłości żadnych zjazdów nie organizował. W kolejnym zalecono, aby wojewoda, który wypowiedział posłuszeństwo królowi, ponowił przysięgę wierności. „Adherenci jego, których z sobą do łaski JKMci pociągał, mają także formalem przysięgę uczynić JeKMci”'13. Następne dwa punkty dotyczyły podjęcia się na własny koszt wyjazdu z obediencją do papieża oraz wyprawienia znacznego pocztu na wojnę z Moskwą, jeśli do niej dojdzie. Wreszcie nakazano M. Zebrzydowskiemu, aby się pojednał z tymi senatorami i urzędnikami, z którymi ma zatargi. Miał też zrezygnować z procesów sądowych ${ }^{14}$. Warto podkreślić, że Zygmunt III w ogóle nie przewidywał zwołania konwokacji senatu. Zebrzydowski miał przyznać na rokoszańskim zjeździe warszawskim, a następnie na sejmie, że pobłądził. Miał też króla przeprosić osobiście, nie wiadomo jednak, czy tej ceremonii mieli towarzyszyć senatorowie. W sumie warunki były dla wojewody krakowskiego bardzo uciążliwe.

Nie wiadomo czy M. Zebrzydowski, formułując swoje postulaty, znał dokładnie warunki królewskie, wolno jednak przypuszczać, że jakieś informacje do niego dotarły. W każdym razie zarówno pomysły monarchy jak i przywódcy rokoszu miały oficjalną datę ogłoszenia niemal równoczesną. Wśród warunków, jakie stawiał królowi wojewoda krakowski na przełomie września i października, najważniejszy dotyczył zwołania przez prymasa Maciejowskiego konwokacji senatu, która podjęłaby się pogodzenia przywódców rokoszu z monarchą ${ }^{15}$. Obradujący w Piotrkowie synod biskupów koronnych wysłał 12 października poselstwo do rokoszan przebywających na zjeździe warszawskim we wsi Kamień. Biskupi zaoferowali radykalnym opozycjonistom mediację. O zjeździe rokoszowym warszawskim autor napisał studium, teraz zatem należy przypomnieć tylko podstawowe kwestie. Otóż zgromadzeni pod Warszawą przyjęli życzliwie ofertę biskupów. W instrukcji z 18 października danej posłom postulowano: „aby JeMć [prymas] Senat jako naprędzy na miejsce sposobne in centro regni convocować raczeł, s którym żeby sposobów gruntownego uspokojenia w Rptej szukał,

11 E. Opaliński, Zjazd rokoszowy warszawski w październiku 1607 r., „Kwartalnik Historyczny”, 121/2014, nr 3, s. 523-524, także T. Kempa, Postawa kasztelana krakowskiego Janusza Ostrogskiego w okresie rokoszu Zebrzydowskiego, w: Wobec króla i Rzeczpospolitej. Magnateria w XVI-XVIII wieku, red. E. Dubas-Urwanowicz, J. Urwanowicz, Kraków 2012, s. 290.

12 B. Czart. 341, s. 892.

13 Ibidem, s. 891.

14 Ibidem, s. 892.

15 E. Opaliński, op. cit., s. 530-531. 
przełożywszy to IchMciom żeby to s taką pilnością i usilnością czynieli, jakoby i sumieniu swemu i RP winni nie zostali"'16.

Należałoby zatem postawić pytanie, czy prymas pod nieobecność monarchy miał w ogóle prawo do zwoływania konwokacji senatu? Próby odpowiedzi podjęła się Izabela Lewandowska Malec, stwierdzając, że gdy w 1594 r. prymas Stanisław Karnkowski, podczas pobytu Zygmunta III w Szwecji, zwołał konwokację senatu, przybyło na nią jedynie 9 senatorów, a sama decyzja arcybiskupa gnieźnieńskiego spowodowała niechęć tak senatu jak i monarchy ${ }^{17}$. W każdym razie Bernard Maciejowski nie zgodził się zwołać konwokacji senatu bez wiedzy i zgody króla. W trakcie posłuchania udzielonego posłom rokoszowym 23 października stwierdził: „Co się pierwszego punctu o Convocatiej, tej ja złożyć, bez pozwolenia JeK.M nie mogę, starać się jednak pro posse będę, aby nam JKM tego nie bronił, gdysz tam nic się czynić contra Majestatem JKM nie będzie, telko rzeczy do zgody ś. poprowadziem"18.

Szybkie i ugodowe zakończenie obrad warszawskiego zjazdu rokoszowego otworzyło wielomiesięczne pertraktacje z M. Zebrzydowskim. Miały one na celu doprowadzenie do ostatecznego zakończenia rokoszu z możliwością zachowania twarzy przez jego przywódcę i w takiej formule, która odpowiadałaby królowi ${ }^{19}$.

Na temat rokowań między M. Zebrzydowskim a wyznaczonymi przez króla senatorami powstały trzy publikacje. Artykuł Jaremy Maciszewskiego ma charakter wtórny w stosunku do studium Wioletty Urbaniak i w związku z tym nie wnosi wiele nowego ${ }^{20}$. Sama W. Urbaniak przedstawiła rokowania z M. Zebrzydowskim po rozprawie guzowskiej ${ }^{21}$. Z kolei Tomasz Kempa, we wspomnianym powyżej artykule, omówił podjęte tu zagadnienie na kilku stronach. Podkreślić jednak należy, że idealizuje on wyraźnie J. Ostrogskiego. Istniejąca literatura przedmiotu zwalnia z obowiązku dokładnego przedstawienia rokowań prowadzonych z M. Zebrzydowskim. Autor chciałby jednak zwrócić uwagę na kilka kwestii związanych z tymi rozmowami.

Można się zgodzić z W. Urbaniak, że Zygmunt III świadomie powierzył pertraktacje z wojewodą krakowskim byłym zamoyszczykom ${ }^{22}$. Prowadzili je początkowo, od schyłku października, dwaj biskupi: Piotr Tylicki, krakowski, i Wojciech Baranowski, kujawski. J. Maciszewski, charakteryzując postawę biskupa krakowskiego jako negocjatora, stwierdza, że „Tylicki był zwolennikiem udzielenia rokoszanom amnestii, uwolnienia więźniów i nienaruszania godności osobistej wojewody krakowskiego za cenę wyrażenia obediencji królowi, złożenia uroczystych przeprosin i wycofania oskarżeń miotanych na osobę monarchy"23. Warto porównać tę opinię z warunkami stawianymi przez Zygmunta III M. Zebrzydowskiemu. W obu wypadkach występuje zgoda na amnestię dla rokoszan, złożenie uroczystych

\footnotetext{
16 Ibidem, s. 534.

17 I. Lewandowska-Malec, op. cit., s. 92-93.

18 E. Opaliński, op. cit., s. 534.

19 Ibidem, s. 538.

20 J. Maciszewski, Próby mediacyjne Piotra Tylickiego w dobie rokoszu sandomierskiego (1606-1608), w: Kościót w Małopolsce, red. W. Kowalski, J. Muszyńska, Kielce 2001, s. 321-330.

21 W. Urbaniak, Zamoyszczycy bez Zamoyskiego. Studium dekompozycji ugrupowania politycznego, Warszawa 1995.

22 Ibidem, s. 128.

23 J. Maciszewski, op. cit., s. 229.
} 
przeprosin i wycofania oskarżeń pod adresem panującego. Właściwie jedyna różnica dotyczy godności osobistej wojewody, którą królewska forma przeprosin mogła naruszać.

Henryk Schmitt w monografii o rokoszu stwierdził, że po synodzie w Piotrkowie, zakończonym w połowie października, król powierzył starania o zgodę z Zebrzydowskim P. Tylickiemu i W. Baranowskiemu, którzy po czterech tygodniach zrezygnowali z mediacji. Autor ten, jako jedyny, pisał o problemie kwarty, stanowiącej zasadniczą kwestię niepozwalającą wojewodzie krakowskiemu na jakikolwiek kompromis ${ }^{24}$. Należy pokrótce wyjaśnić istotę tego problemu. Otóż przywódca rokoszu dokonał defraudacji pieniędzy publicznych. Bowiem zamiast przekazać kwartę ze swoich starostw, zatrzymał ją u siebie i przeznaczył na potrzeby ruchu, któremu przewodził. Do kwestii tej przyjdzie jeszcze wrócić, na razie podjęta zostanie sprawa ewentualnego zwołania konwokacji senatu i tego, kto ma ją zwołać.

Jak informował pisarz królewski Jan Zawadzki Szymona Rudnickiego, biskupa warmińskiego, w liście z 29 XI 1607, Zygmunt III zwołuje do siebie niektórych senatorów ,jako IchM. X. Biskupa Krakowskiego, Kujawskiego, którzy już przybyli a Pana Wojewody i Kastellana Poznańskiego, Pana Krakowskiego, Pana Referendarza"25. Warto zauważyć, że byli to zarówno negocjatorzy królewscy, jak i najwierniejsi królowi - H. Gostomski, wojewoda poznański, Szczęsny Kryski, referendarz koronny i wkrótce podkanclerzy, Jan Ostroróg kasztelan poznański, regalista umiarkowany, a wcześniej związany z Zamoyskim, oraz Janusz Ostrogski, który zresztą na naradzie się nie pojawił. Zdaniem J. Zawadzkiego narada ta miała rozstrzygnąć, czy uspokojenie Rzeczypospolitej nastąpi na sejmie, czy też na konwokacji senatu, co popierał kasztelan krakowski, chcący, ,aby przez X. Arcybiskupa złożona była”. Jak się wydaje, zapadła wówczas wstępna decyzja o zwołaniu konwokacji przez króla. Z całą pewnością S. Żółkiewski nie był wówczas desygnowany na mediatora, gdyż na naradę nie był wezwany. Tak więc misja obu biskupów trwała nadal. O jej końcu mówi list P. Tylickiego do Wawrzyńca Gembickiego, biskupa chełmińskiego, z 18 XII 160726. Biskup krakowski opisuje swój i biskupa kujawskiego trud „dla łatania i umiarkowania tych rozróżnienia”. Ich wysiłki przyjęto niewdzięcznie, jednak udało się załatwić niekaranie Zebrzydowskiego za „wzięcie” kwarty i przekazanie dalszej mediacji hetmanowi polnemu koronnemu. Można więc przyjąć, że misja Tylickiego i Baranowskiego nie trwała 4 tygodnie, jak twierdził błędnie Schmitt, lecz co najmniej osiem tygodni - mniej więcej od połowy października do połowy grudnia. W kolejnym liście do biskupa chełmińskiego, pisanym z Kielc 5 stycznia 1608, P. Tylicki pesymistycznie oceniał możliwość porozumienia się z Zebrzydowskim: „do conditiej owych podanych nie barzo, aby jeszcze przypadał i widzę około kwarty declaratiej nie barzo wysoce kładzie" ${ }^{27}$. Z listu wynika jednoznacznie, że to Żółkiewski prowadzi pertraktacje, ale obaj biskupi są nimi bardzo zainteresowani. Tylicki uważa nawet, że mogą nastąpić niepokoje, jeśli ugoda nie nastąpi: „Jusz copie jakichś uniwersałów latają między ludźmi pod tytułem JMP Krakowskiego i kilku innych na Conwocatią, albo do kupy raczej zwołując. Nie barzo mi się wierzyć chce, aby prawdziwe to beły copie, a to przedsię mieszają jemi ludzi”. W. Urbaniak zna ten list, ale opatrzyła go błędną sygnaturą (vol. 63) i stwier-

\footnotetext{
24 H. Schmitt, Rokosz Zebrzydowskiego, Lwów 1858, s. 556, 554.

25 J. Zawadzki do S. Rudnickiego, Kraków, 29 XI 1607 - B. Czart. 1639, k. 263-265.

26 P. Tylicki do W. Gembickiego, Kielce, 18 XII 1607 - Riksarkivet Stockholm, Extranea IX Polen, vol. 103 (dalej: Extranea IX).

27 P. Tylicki do W. Gembickiego, Kielce, 5 I 1608 - Extranea IX, vol. 103.
} 
dziła, że wysłano go z tajemniczej miejscowości Klecze ${ }^{28}$. Przesadnie też określiła poziom zagrożenia rokoszem w ocenie Tylickiego, który wyraźnie stwierdza, że w prawdziwość uniwersałów wzywających szlachtę nie wierzy. Inna sprawa, że Zebrzydowski próbował do końca stwarzać wrażenie, że grozi wznowienie rokoszu.

Warto wspomnieć, że do roli czołowego mediatora pretendował Janusz Ostrogski, kasztelan krakowski. T. Kempa wskazuje na list kasztelana krakowskiego do prymasa z 4 listopada 1607, w którym Ostrogski, chcący zwołania konwokacji senatu przez B. Maciejowskiego, w razie jego odmowy, brał pod uwagę własną osobę ${ }^{29}$. Warto dodać, że pisał on w tej sprawie do prymasa jeszcze w grudniu, a po jego śmierci próbował przekonać do własnej osoby arcybiskupa lwowskiego ${ }^{30}$. Jak stwierdza T. Kempa, w końcu kasztelan krakowski zmienił koncepcję i w liście do króla z 26 stycznia zaproponował, aby to Zygmunt III zwołał konwokację senatu. Nie było to jednak poparcie monarchy, bowiem jednocześnie proponował uznanie artykułów sandomierskich, co spotkało się z ostrą ripostą króla w liście z 20 lutego ${ }^{31}$.

Zostaną teraz przedstawione działania M. Zebrzydowskiego mające na celu uzyskanie jak najlepszych warunków ugody z królem. Forsowanie koncepcji zwołania konwokacji senatu przez prymasa, ewentualnie przez kasztelana krakowskiego, mogło być zabiegiem służącym do późniejszego obniżenia tych wygórowanych żądań. Z pewnością bowiem wojewoda krakowski, będąc wytrawnym politykiem, nie mógł wierzyć, że Zygmunt III zgodzi się na jego propozycje. Mimo to wojewoda krakowski podejmował działania sondujące możliwość zwołania konwokacji senatu w takiej właśnie formie. W tym celu na początku 1608 roku wystosował listy do wielu senatorów, w których przedstawiał się jako ofiara gry politycznej króla i regalistów oraz obarczał dwór odpowiedzialnością za zwłokę w rozmowach o uspokojeniu RP. O akcji tej wspomina H. Schmitt. Przytacza także dwie odpowiedzi. Jedna z nich to list Adama Sędziwoja Czarnkowskiego, starosty generalnego Wielkopolski i wojewody łęczyckiego, w którym wojewoda nakłania do przyspieszenia rokowań i wypomina wypowiedzenie posłuszeństwa królowi „na prywatnym zjeździe”. Omawia także drugi respons, w którym anonimowy senator z Małopolski pochwala działania Zebrzydowskiego ${ }^{32}$. Zabieg zastosowany przez H. Schmitta stwarza fałszywe wrażenie, jakoby zabiegi wojewody krakowskiego popierała znaczna część senatorów. Tymczasem znane jest co najmniej dziesięć responsów senatorskich i wszystkie one są bardzo nie po jego myśli ${ }^{33}$. Wojewoda krakowski wystosował ponadto listy do szlachty na początku stycznia 1608. Miały one treść podobną do listu do senatorów, a nadawca prosił o radę, co ma w tej sytuacji czynić. „Proszę tedy, aby mój Mciwy porozumiawszy się z drugimi obywatelami województwa tamtego zdanie swoje oznajmić raczył"34. Akcja ta wygląda na próbę mobilizowania swoich zwolenników.

28 W. Urbaniak, op. cit., s. 130.

29 T. Kempa, op. cit., s. 292.

30 J. Ostrogski do B. Maciejowskiego, Ostróg, 23 XII 1607 - TN 103, s. 763; J. Ostrogski do J. Zamoyskiego, arcybpa lwowskiego, Ostróg, 25 I 1608 - TN 104, s. 27.

31 T. Kempa, op. cit., s. 292.

32 H. Schmitt, op. cit., s. 560-566.

33 Arcybp lwowski J. Zamoyski - B. Czart. 339, k. 425-426; wda poznański H. Gostomski - ibidem, k. 426-426v; bp kujawski W. Baranowski - TN 104, s. 29-32; kaszt. wileński Hieronim Chodkiewicz - B. Racz. 18, k. 198-199; kaszt. poznański Jan Ostroróg - ibidem, k. 192v-193; wda sieradzki Aleksander Koniecpolski - ibidem, k. 194v-196v; bp chełmiński W. Gembicki - Extranea IX, vol. 115; kaszt. gnieźnieński Andrzej Przyjemski - TN 104, s. 533-536; anonimowy senator regalista - ibidem, s. 37-39.

34 TN 104, s. 1. 
Jak wynika z listu Samuela Targowskiego do biskupa warmińskiego z 15 grudnia 1607 roku, Zebrzydowski prowadził z królem podwójną grę. Targowski podkreślił, że przywódca rokoszu nie jest szczery i rokowania z nim nie będą łatwe i szybkie, ,a tym czasem na to się przybliżać i potęgą się sposabiać będzie. Spodziewam się sam tego, że pod Lublinem zjazd będzie po godziech"35. Być może z owym hipotetycznym zjazdem związana była listowna akcja wojewody na początku stycznia 1608 roku, mogło też chodzić o ruchy części oddziałów rokoszańskiego wojska pod wodzą pułkownika Ludwika Poniatowskiego, które ostatecznie w marcu znalazło się w Krasnymstawie. Z korespondencji Targowskiego wynika także, że w tym czasie rokowania z wojewodą krakowskim przejął S. Żółkiewski, do niego bowiem został wysłany przez króla z instrukcją dotyczącą mediacji ksiądz Stanisław Sułowski, od marca opat tyniecki.

Jak wiadomo do żadnego zjazdu w Lublinie na początku 1608 roku nie doszło, a w marcu warunki ugody były już wstępnie uzgodnione. Jak informował W. Gembicki S. Rudnickiego w liście z 11 marca król zdecydował już, ,aby zwołać do siebie Senatorów pono przedniejszych, ale P. Hetman miał snadź radzić zatrzymać się z tym, ażby się widział P. Wojewodą Krakowskim, który w Zamościu"36. H. Schmitt przytacza list kasztelana lwowskiego do wojewody krakowskiego z 20 marca 1608. Żółkiewski informował w nim adresata, że król daruje mu kwartę, ale musi o to zabiegać zgodnie z prawem na sejmie. Zygmunt III zgodził się również na zwołanie konwokacji, pod warunkiem, że przywódca rokoszu wpierw przeprosi go osobiście ${ }^{37}$.

O ostatecznych warunkach porozumienia, jakie w marcu ustalił kasztelan lwowski z wojewodą krakowskim, donosi W. Gembicki biskupowi warmińskiemu 21 marca. Informuje go, że król zwołał konwokację senatu na 24 kwietnia ${ }^{38}$. Zna ten list W. Urbaniak, która zauważyła, że Zebrzydowski obiecał rezygnację ze stawienia się zbrojnego w Krakowie, miał też złożyć oświadczenie przed senatem, a następnie sejmem o złym informowaniu o królewskich praktykach, przeprosić króla zgodnie z procedurą opracowaną przez senatorów, a w zamian otrzymać przebaczenie, również dla swych „,przyjaciół”, jeśli o to osobiście wystąpią

Nie oznaczało to jednak kapitulacji Zebrzydowskiego. W dniu 25 lub 28 marca zawiązała się bowiem pod wodzą pułkownika L. Poniatowskiego konfederacja wojska rokoszowego w Krasnymstawie. Można się zgodzić z W. Urbaniak, że mogła to być karta przetargowa przywódcy rokoszu ${ }^{40}$. Żaden z badaczy nie zwrócił jednak uwagi na jeszcze jedną próbę przechylenia szali na swoją korzyść przez wojewodę krakowskiego. Chodzi o jego list z 26 marca do Stanisława Stadnickiego, kasztelana przemyskiego i jednocześnie marszałka Trybunału Koronnego. Otóż wojewoda, powołując się na wypowiedzenie przez rokoszan pod Jezierną posłuszeństwa Zygmuntowi III, zażądał od marszałka trybunalskiego, aby wstrzymał działania sądu, przynajmniej na czas ,„pożądanej satysfactiej, której się już w Polsce wkrótce spodziewamy, gdyż na tym wszystko zawisło"41. Żądanie to jest niesłychane i świadczy o tym,

\footnotetext{
S. Targowski do S. Rudnickiego, Kraków, 15 XII 1607 - B. Czart. 1630, s. 313.

36 W. Gembicki do S. Rudnickiego, Lubawa, 11 III 1608 - B. Czart. 1630, s. 383-384.

37 H. Schmitt, op. cit., s. 556.

38 W. Gembicki do S. Rudnickiego, Lubawa, 21 III 1608 - B. Czart. 1630, s. 397.

39 W. Urbaniak, op. cit., s. 131.

40 Ibidem, s. 132.

41 TN 104, s. 105.
} 
że Zebrzydowski do końca bardzo wysoko licytował w swej grze z monarchą. Postawa ta, sprawiająca wrażenie nie całkiem racjonalnej, miała być może podstawę w nadziejach na połączenie konfederatów wojska inflanckiego w Brześciu z wojskiem rokoszan, skupionym w konfederacji krasnostawskiej ${ }^{42}$.

Zygmunt III uniwersałem z 15 marca 1608 wezwał senatorów na konwokację do Krakowa na dzień 24 kwietnia ${ }^{43}$. Wśród powodów podano na pierwszym miejscu sprawy wewnętrzne, a więc „namówione kondycje” z Zebrzydowskim, „nieuspokojone zaciągi, prywatnych ludzi swawoleństwa, wojska po różnych miejscach nowym rozruchom otuchę dające”. Wskazano więc wyraźnie na groźbę odnowienia rokoszu. Na drugim miejscu postawiono niebezpieczeństwo zewnętrzne, a więc rozruchy na Węgrzech oraz „od Moskwy niepewny pokój”.

W dniu inauguracji konwokacji stawiło się zaledwie 19 senatorów, w tym 5 biskupów (arcybiskup lwowski, biskupi: krakowski, kujawski, płocki Marcin Szyszkowski i przemyski jednocześnie kanclerz koronny Maciej Pstrokoński), 4 wojewodów: poznański, sieradzki, kijowski S. Żółkiewski, podolski Jakub Pretficz oraz 9 kasztelanów: sandomierski Stanisław Tarnowski, wojnicki Sebastian Lubomirski, gnieźnieński, łęczycki Stanisław Bykowski, chełmiński Michał Konarski, biecki Jan Branicki, biechowski Wacław Kiełczewski, sierpski Wojciech Kryski, ponadto kanclerz litewski Lew Sapieha. W trakcie obrad przybyli także biskup chełmiński, kasztelani: kaliski Adam Stadnicki, wiślicki Andrzej Tęczyński i wieluński Jakub Rawita Gawroński oraz podskarbi wielki koronny Jan Firlej. W sumie były zatem 24 osoby $^{44}$. Ostatecznie liczba senatorów powiększyła się nieznacznie, skoro uniwersał konwokacji senatu dnia 9 czerwca podpisali ponadto: wojewoda płocki Stanisław Krasiński, kasztelan zawichojski Piotr Firlej i czechowski Mikołaj Ligęza. Warto też dodać, że swój podpis złożył M. Zebrzydowski ${ }^{45}$. Ogólna liczba uczestników konwokacji nie była imponująca, przy czym zwraca uwagę symboliczna reprezentacja Litwy.

Pierwsza sesja konwokacji odbyła się 28 kwietnia. Król zaproponował na niej do przedyskutowania 7 punktów. Pierwszy z nich dotyczył sposobów, przy pomocy których „od wnętrznych mieszanin miała by bydź Rzpta uspokojona"46, drugi - ustalenia warunków, pod którymi „tych do łaski przyjąć, którzyby jej szukać chcieli”. Kolejny poświęcono sposobom postąpienia z tymi rokoszanami, ,którzyby uporu swego odstąpić nie chcieli i arma w ręku trzymali”. Spraw wewnętrznych dotyczył także ostatni punkt propozycji, w którym chodziło o zahamowanie zaciągów czynionych przez osoby prywatne. Pozostałe związane były z problemem bezpieczeństwa zewnętrznego: kwestia inflancka, ewentualny rozejmu z Karolem Sudermańskim oraz zakaz zaciągania się do wojsk moskiewskich.

Senatorowie radzili, aby „Do uspokojenia Rzptej od wnętrznych mieszanin raczej łaskawych niż surowych srzodków zażyć". Zalecali także napisanie listu do wojewody krakowskiego, aby przybył na konwokację do Krakowa ,i przystał na wynalazku Panów Senatorów i srzodków, któremi by do łaski KJM. miał być przypuszczony”. Rokoszan, „którzy chcą łaski królewskiej”, chciano wezwać do przeprosin ,przez edykt”, a tych którzy tym pogardzą, aby na sądzie sejmowym karano zgodnie z prawem pospolitym, zaś inflanckie garnizony „z Reszt

42 W. Urbaniak, op. cit., s. 135.

43 B. Czart. 341, s. 1010.

44 Ibidem, s. 1032.

45 B. Czart. 337, s. 704-705.

46 B. Czart. 341, s. 1033. 
Poborowych a z części jakiej Quarty teraźniejszej opatrzeć”. Senatorowie proponowali także powołanie komisji do „traktowania z strony Inducyj z Xiążęciem Carolussem”. Poza tym zalecano neutralność wobec walk wewnętrznych w Moskwie i zahamowanie wyjazdów do tego państwa „edyktem”. „Tych, którzy querry wszczynają i dla prywatnych zaciągów wojsko na się zwodzą autoritate tego zjazdu napomnieć", aby zdali się na mediację króla i senatorów, „a jeśliby słuchać nie chcieli na Sejm cum delatore zapozwać”47. Próbowano więc zapobiec prywatnej wojnie między Łukaszem Opalińskim a Stanisławem Diabłem Stadnickim.

Kilka dni poświęcono na przygotowanie listu do M. Zebrzydowskiego. Pismo senatu datowano na 4 maja. Senatorowie przypomnieli w nim starania własne i królewskie podejmowane w latach 1606-1608 w celu uspokojenia państwa. Wspomnieli o mediacji S. Żółkiewskiego, w wyniku której M. Zebrzydowski zgodził się na warunki senatu i zobowiązał się do przyjazdu na konwokację. Wezwano go przeto do stawienia się w Krakowie na dzień 16 maja $^{48}$. Do listu załączono „Srzodki przez które JeMć Pan Wojewoda Krakowski do łaski JeK. M. przyjść miał przez PP. Senatory umoderowane"49. Warunki były identyczne z tymi wynegocjowanymi przez Żółkiewskiego w marcu 1608. Dodano jedynie żądanie akceptacji konstytucji sejmu 1607 roku. Do Zebrzydowskiego wysłano sędziego ziemskiego lwowskiego Piotra Ożgę wyposażonego w instrukcję, w myśl której miał się starać, aby wojewoda przybył szybko do Krakowa oraz zadeklarował, że akceptuje warunki senatu. Ożga powinien czekać nie dłużej, ,jedno tak, żeby tu mógł zjechać sam Pan Sędzia najdalej ad XIII maja”. Jeśliby Zebrzydowski z ważnych powodów na czas nie mógł przyjechać, ma podpisać akceptację warunków senatu i zobowiązanie do przeproszenia monarchy. Może też dostać asekurację od senatu, którą mu poseł przekaże ,za pewną cautią od P. Wojewody Krakowskiego jemu daną"50.

Kolejne posiedzenie konwokacji senatu miało miejsce 6 maja. Czytano wówczas listy od arcyksięcia Macieja, od władz Rygi i od Szwedów. Król proponował ustalenie odpowiedzi na pismo arcyksięcia oraz wysłanie poselstwa do cesarza - ,wiodąc ich do zgody" ${ }^{51}$. Kolejne punkty propozycji to odpowiedź na korespondencję od Szwedów i ewentualna zgoda na wymianę z nimi jeńców. Ostatnia kwestia do dyskusji to: „Jako Ryżany na postulata ich odprawić". Senatorowie zaproponowali, aby napisać do arcyksięcia Macieja i wysłać poselstwo do cesarza z propozycją mediacji mającej doprowadzić do zgody. Ustalono też, aby powołać komisję do zawarcia rozejmu i wymiany jeńców ze Szwecją. Zaproponowano wreszcie dać odpowiedź ,gładką” na postulaty „Ryżan”, pochwalić ich wierność i dać nadzieję ratunku. Kwestie te dyskutowano także na innych posiedzeniach, więc autor nie będzie tu do nich wracać.

Następna sesja konwokacji senatu odbyła się dopiero 17 maja. Trzeba przypomnieć, że wojewoda krakowski miał się stawić na jej posiedzeniu dzień wcześniej. Tymczasem właśnie 17 maja relację ze swojej misji zdawał sędzia lwowski. Senatorowie nie byli zadowoleni, że wojewoda krakowski nie określił terminu przybycia do Krakowa - „condonować to jednak inquitati temporum et desiderie pacis publicis, contentowali się IchMPP Senatorowie”.

\footnotetext{
47 Ibidem, s. 1034.

48 Ibidem, s. 1035-1036.

49 Ibidem, s. 1037-1038.

50 Ibidem, s. 1038-1039.

51 Ibidem, s. 1039.
} 
Czytano także list od „Margarety Wojewodziny Wołoskiej”. W tej sprawie radzono napisać do hospodara mołdawskiego z upewnieniem królewskim, ,że provisją przystojną będzie opatrzona i bezpieczeństwie z strony zdrowia swego i dziatek swych" 52 .

List Zebrzydowskiego, przywieziony przez Ożgę, ma datę 11 maja. Jego autor potwierdza chęć przyjazdu na konwokację, ale dopiero po wyzdrowieniu. Warto zwrócić uwagę na niesłychaną hipokryzję wojewody krakowskiego, który wbrew faktom czynił z siebie gołąbka pokoju, starającego się podczas rokoszu „rzeczy” uspokajać i ,panowanie JKM utwierdzić”,53.

Następne posiedzenie konwokacji senatu zwołano 20 maja. Trzy punkty narady dotyczyły kwestii rokoszowych. Miano ustalić, do kiedy czekać na Zebrzydowskiego, co zrobić z tymi, którzy wypowiedzieli posłuszeństwo królowi, a nie zechcą ponowić przysięgi wierności, wreszcie „co czynić z więźniami na Zamku Krakowskim będącymi”"54. Postanowiono, by na przyjazd wojewody krakowskiego czekać do 29 maja, ,a jeśli na czas naznaczony nie stawi przez piątek i sobotę dalsze środki do uspokojenia Rzptej namówić”. Nie uzgodniono natomiast, jak postąpić z tymi, co nie chcieli ponownie przysięgać na wierność. Senatorowie radzili też, aby trzymanego w więzieniu na Wawelu Prokopa Pękosławskiego wypuścić, odebrawszy od niego przysięgę na wierność i wziąwszy „kaucję, że się więcej w sprawy Rzptej nie ma mieszać”. Natomiast Szczęsnego Herburta sugerowano do sejmu zatrzymać w więzieniu, „o którym jest suspicia niemała, że z Pany Cudzoziemskimi o Królestwo practicował".

W dniu 23 maja odbyło się kolejne posiedzenie konwokacji. Dyskutowano nad tym, jak zahamować zaciąganie wojsk prywatnych przez podczaszego litewskiego Janusza Radziwiłła i starostę żmudzkiego Jana Karola Chodkiewicza oraz przez starostę leżajskiego Ł. Opalińskiego i S. Stadnickiego. Postanowiono wysłać do nich posłańców z żądaniem, aby wojska rozpuścili i zdali się „na uważenie Króla JM i PP. Senatorów”55.

Dzień później zebrano się ponownie. Kontynuowano poprzednie tematy. Ustalono, że do J. Radziwiłła i J. K. Chodkiewicza zostanie wysłany referendarz duchowny koronny Henryk Firlej, a do Ł. Opalińskiego i S. Stadnickiego opat tyniecki Stanisław Sułowski, aby ich pojednać. Chciano także, aby rokoszanin Stadnicki wystąpił o łaskę królewską. Ponadto czytano listy od hetmana Chodkiewicza „z strony niebezpieczeństw Inflantskich"56.

Sesję wznowiono 26 maja. Zatwierdzono treść listów i instrukcji dla referendarza koronnego i opata tynieckiego. Przygotowano ponadto listy do wojewodów, wileńskiego Mikołaja Krzysztofa „Sierotki” Radziwiłła i lubelskiego Gabriela Tęczyńskiego oraz do kasztelana krakowskiego, aby wpłynęli bezpośrednio lub pośrednio na oponentów ${ }^{57}$.

W liście datowanym na 25 maja do J. Radziwiłła stwierdzono, że tak do senatorów jak i do króla doszły wieści o zbieraniu wojska przez podczaszego litewskiego, które uciska ludność w dobrach królewskich, duchownych i szlacheckich. Zażądano, aby Radziwiłł wojsko rozpuścił i nie dawał okazji hetmanowi litewskiemu. Co więcej, wysłannik senatu, Firlej, miał wziąć od Chodkiewicza pisemną asekurację bezpieczeństwa dla Radziwiłła,

Ibidem, s. 1040, 1041

53 Ibidem, s. 1041-1042.

54 Ibidem, s. 1042.

55 Ibidem, s. 1043-1044.

56 Ibidem, s. 1044.

57 Ibidem, s. 1045. 
a podczaszy odwołać ludzi ze starostwa kobryńskiego i dóbr duchownych, a „osobliwie Poniatowskiego z jego ludźmi, aby JeM przy sobie nie bawił i aby go odstąpił”. Jak napisano, w razie odmowy król postąpi według surowości prawa ${ }^{58}$.

Instrukcja dla H. Firleja z dnia 27 maja w znacznym stopniu pokrywa się z listem senatu do Radziwiłła. Zawiera jednak kilka nowych, przeważnie technicznych elementów. Poseł miał wysłać listy do Radziwiłła i Chodkiewicza, wojewodów wileńskiego i lubelskiego, a sam jechać do hetmana litewskiego, by go upomnieć, aby na Litwie ,z prywatnych jakichsi nieprzyjaźni do niemałych rozruchów" nie dochodziło. Po uzyskaniu od Chodkiewicza asekuracji dla Radziwiłła powinien się on wywiedzieć o przyczyny prywatnej nieprzyjaźni z podczaszym litewskim oraz jednać ich przez wymienionych wyżej wspólnych przyjaciół ${ }^{59}$. Taką samą datę ma list senatorów do kasztelana krakowskiego, w którym informują adresata o wysyłaniu H. Firleja z misją na Litwę. Proszą też o pomoc, zwłaszcza o przekonanie do zgody swego siostrzeńca.

Sam Janusz Radziwiłł przysłał na konwokację senatu list z datą 27 maja. Autor przedstawił siebie jako człowieka spokojnego, którego prywatny nieprzyjaciel, bez żadnych powodów, zamiast iść do Inflant, zaatakował na Podlasiu ${ }^{60}$.

Odpowiedź senatu nosi datę 7 czerwca, wtedy gdy senatorowie są pewni, że u Radziwiłła zjawił się już ksiądz referendarz. Piszą, że nakazali w imieniu króla i swym, aby hetman litewski nic prywatnego przeciw niemu nie czynił. Wyrzucają też podczaszemu, że jego sługa Grądzki, mając audiencję w senacie „,nieostrożnie i słowy przykremi niektóre rzeczy wspominał", szczególnie, że hetman czynił je z rozkazania królewskiego ${ }^{61}$.

Audiencja, której udzielił senat Grądzkiemu miała miejsce 2 czerwca. Wypowiedź sługi radziwiłłowskiego jest ciekawa, choć mija się on częściowo z prawdą. Oświadczył mianowicie, że Radziwiłł „po rozprawie pod Guzowem” zapragnął spokojnie siedzieć w domu, co nie było prawdą, gdyż 11 lipca w Lublinie wydał uniwersał wzywający całą szlachtę na zjazd elekcyjny pod Warszawę na 5 sierpnia. Wg Grądzkiego do zachowania spokoju zachęcali podczaszego litewskiego kasztelan krakowski, wojewoda wileński, kasztelan trocki Jerzy Radziwiłł i kanclerz litewski, obiecując za staraniem samego senatu gruntowanie uspokojenie RP. Zaczym Radziwiłł, jak stwierdził, „do żadnych zjazdów ani fakcyj nie wiązał się, ale doma pożądanego pokoju czekał" - co w tym wypadku było prawdą. Opisując, jak prześladował go Chodkiewicz, nawet w czasie jazdy na pogrzeb wojewody kijowskiego Konstantego Ostrogskiego, użył sformułowania, że hetman litewski napastuje szlachtę z rozkazania królewskiego ${ }^{62}$. Właśnie te słowa spowodowały oburzenie senatorów.

W wyniku mediacji J. K. Chodkiewicz wystosował z datą 6 czerwca asekurację dla J. Radziwiłła ${ }^{63}$. Zatem misja Firleja zakończyła się pomyślnie i 20 czerwca zawarto rozejm między obu antagonistami.

\footnotetext{
Ibidem, s. 1045-1046.

Ibidem, s. 1050.

Ibidem, s. 1053-1054.

Ibidem, s. 1055-1056.

BN III 3087, s. 5010-5012.

B. Czart. 341, s. 1057.
} 
Na sesji senatu 30 maja postanowiono czekać na Zebrzydowskiego, który nie dotrzymywał kolejnego terminu, do 2 czerwca. Sprawę zabezpieczenia Inflant zdecydowano „odłożyć do uspokojenia domowych rozruchów"64.

2 czerwca omawiano z kolei problem złamania przez Zebrzydowskiego warunków przyjazdu na Wawel. Otóż wojewoda, będąc już w Mogile, postanowił przybyć z liczną uzbrojoną świtą. Zdecydowano wysłać do niego Żółkiewskiego, aby przypomnieć ustalone warunki wjazdu na zamek krakowski ${ }^{65}$.

Sesje konwokacji odbyły się również w dniach 3 i 4 czerwca. Następnego dnia, z powodu Bożego Ciała, obrad nie było. 3 czerwca wyznaczono Zebrzydowskiemu audiencję na szóstego o godzinie 9, 4 czerwca Żółkiewski referował swoje spotkanie z Zebrzydowskim, informując, że jest on gotów wypełnić wszystkie warunki ${ }^{66}$.

Audiencja w senacie opisana jest dokładnie w materiałach Andrzeja Lisieckiego. Opisał ją także H. Schmitt, którego narracja często mija się z przekazami źródłowymi. Na salę audiencyjną wybrano komnatę, w której było wesele królewskie. Na ścianach, mających kolor zielony, wymalowana była zwycięska bitwa z arcyksięciem Maksymilianem. Wolno przypuszczać, że wybór ten był bardzo przemyślany, gdyż wystrój z jednej strony przypominał związki z Habsburgami, z drugiej zaś zwycięstwo nad arcyksięciem, co uderzało w narrację rokoszan posądzających Zygmunta III o zbytnie uleganie wpływom tej dynastii ${ }^{67}$. H. Schmitt stwierdza, że wojewoda krakowski stawił się w Krakowie w terminie, a przecież spóźnił się on ponad dwa tygodnie ${ }^{68}$. Wjazd Zebrzydowskiego do Krakowa (z Mogiły) odbył się zgodnie z ustaleniami senatu, a więc towarzyszyło mu jedynie 30 jezdnych i 50 piechoty. „Z Panow Senatorów żaden, ani go prowadził, ani przeciw niemu wyjeżdżał”. Tymczasem H. Schmitt pisze, że towarzyszył muŻółkiewski ${ }^{69}$. Po zajęciu miejsca pod baldachimem przez króla i zajęciu miejsc przez senatorów, kanclerz litewski, pełniący obowiązki marszałka, wyszedł po Zebrzydowskiego, który przemówił do monarchy, tłumacząc swe postępowanie. Podkreślił, że nie czynił niczego z niechęci do króla, którego dostojeństwa zawsze bronił, ale działał dla dobra Rzeczypospolitej. Jednak widząc, że tak senatorowie, jak i „wiele ludzi stanu Rycerskiego inaczej to widziało", stosując się do tego, prosi króla, aby mu jego mniemania i czyny darował i do łaski przywrócił. Ponawia przy tym przysięgę wierności ${ }^{70}$. W imieniu monarchy respons dał Maciej Pstrokoński, kanclerz koronny i biskup przemyski, przypominając, jak za przyczyną Zebrzydowskiego gwałtowne niebezpieczeństwo na ojczyznę przyszło ,i dostojeństwo JeKM nieuszanowane, powaga Senatu zelżona, prawa i zwyczaje ojczyste pomieszane, nie przepłacona wolność swąwolą naruszona”. Podkreślił jednocześnie, że monarcha, rozumiejąc, że za grzechy Bóg „to karanie przypuścił”, tych, którzy opowiadają się ponownie za posłuszeństwem królowi, przywróci do łaski ${ }^{71}$. Po czym

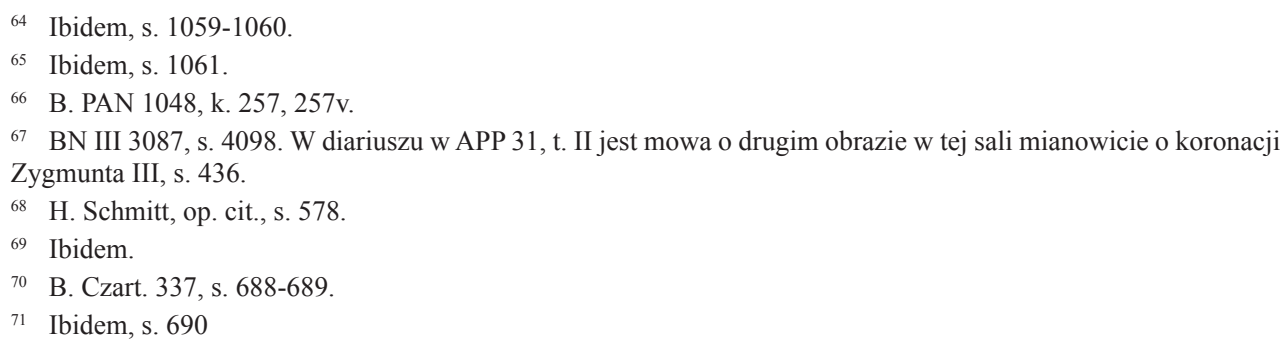


wojewoda ,przystąpił z wielką uczciwością do Króla JeMci, rękę całował, przywitał i za nogi obłapiał"'72.

Następnie Zebrzydowski wygłosił mowę do senatu. W jej trakcie wszyscy senatorowie stali. Zaczął od tego, że zawsze chciał jak najszybciej stawić się w ich gronie, ,ale słuszne przyczyny tego nie dopuszczały". Zatem prosi, aby się na niego nie obrażano. Deklarował, że zalecenia senatu wypełnił, wszystko, co czynił, czynił z najlepszymi chęciami, a teraz chce się przyczynić do uspokojenia $\mathrm{RP}^{73}$. Odpowiedział mu w imieniu senatu arcybiskup lwowski, który oświadczył, że „złe zdrowie” króla nie pozwala na długie mowy, ale cieszy się, że wojewoda chce zgody, zażądał też, aby wygłosił mowę na najbliższym sejmie - ,aby ludzie dalej w opiniach już się nie bawili i tych tumultów nie czynili”. Dziękował również królowi w imieniu senatu, że przyjmuje rokoszan do łaski ${ }^{74}$.

„Die septima Junii nie był Pan Wojewoda in Senatu bo zachorzał był na podagrę z długiego snadź na sali stania”75. W dniu tym „Pan Podsędek Lubelski [Jan Dzierżek] iustificował postempki swoje a mianowicie, że invitus wypowiedział posłuszeństwo a prosił, aby i do łaski JeKM był przypuszczony i do wiosek był przywrócony"76. Wojewoda zjawił się w senacie 9 czerwca i podpisał uniwersał konwokacji. „Die decima jechał rano do Pacanowa dla złego barzo zdrowia Paniej Wojewodzinej"77.

Z kolei 14 czerwca stawił się Zygmunt Grudziński, wojewoda rawski. Przepraszał króla wg procedury zastosowanej wobec M. Zebrzydowskiego. On również „był uwiedziony zelo libertatatis, rozumiejąc, że się Rzptej w czym nie dosyć działo”. Prosił zatem monarchę o wybaczenie i przyjęcie do łaski.

Odpowiedział i przebaczył mu w imieniu króla kanclerz koronny M. Pstrokoński ${ }^{78}$. „Po tym całował rękę JK”. Na mowę do senatu tym razem dał respons biskup płocki Szyszkowski, który uznał, iż to, co się wydarzyło, to kara Boska za grzechy. „Pan Bóg zaś niewinność J.K.M. niewinność nasze i wszytkich, którzy przy boku J.K.M. stanęli pokazał. Pan Bóg i teraz Rzpty do skutecznego uspokojenia prowadzi”. I dalej: „Co się tknie naszej urazy, jakośmy to na Pana Boga puścieli i jakośmy wiedli JKM do tego, aby urazy swe w niepamięć podał", tak i oni wybaczają 79

Następnie wg procedury zastosowanej przy J. Dzierżku przepraszał monarchę Piotr Łaszcz, który podobnie jak poprzednicy stwierdził: „W tych żałosnych a opłakanych zamieszanej ojczyzny naszej czasiech uwiedziony i użyty od niektórych Braci Województw Wielgopolskich dałem się był użyty do tej tam gromady rozumiejąc, że było coś takiego, aby nas słusznie z domów naszych poruszać miało”, „sam nigdy na panowanie W.K.M. nie nacierał, mówię to dobrze porachowawszy się z sobą. A jako to przed Majestatem W.K.M. declaruję się, tak i przed bracią, od któryjem był użyty z tym stanę, żem nic nad pozwolenie

\footnotetext{
BN III 3087, s. 4099.

B. Czart. 337, s. 691.

Ibidem, s. 693.

BN III 3087, s. 4099.

B. PAN 1048, k. 259v.

BN III 3087, s. 4099.

Ibidem, s. 5000-5001.

Ibidem, s. 5002-5003.
} 
ich nie czynił i przeciw dostojeństwu WKM niczem niepostąpił, samym tylko przywiązaniem do nich".

„Zaczym JKM zaraz rękę swą ściągnął, że Pan Łaszcz i przed daniem responsu rękę KJM całował". Odpowiedział Łaszczowi, również stereotypowo, kanclerz koronny, konkludując, że ponieważ Łaszcz żałuje „tego uniesienia swego”, więc mu przebacza ${ }^{80}$.

Wg W. Urbaniak w dniu 14 czerwca przepraszali monarchę nie tylko Zygmunt Grudziński i Piotr Łaszcz, ale ponadto: Wawrzyniec i Stefan Kazimierscy, Stanisław Cikowski, podkomorzy krakowski, Piotr Adamowicz, podsędek żmudzki, Jan Szczęsny Herburt i Prokop Pękosławski. Autorka stwierdziła błędnie, że Herburt został zwolniony w dniu $10 \mathrm{kwietnia}^{81}$. Nie było to jednak możliwe, skoro na konwokacji w dniu 20 maja ustalono jego dalsze zatrzymanie. Fakt przepraszania króla przez Herburta w trakcie konwokacji senatu potwierdza także H. Schmitt, jednak nie podaje, którego dnia miało to nastąpić. Przytacza on także mowę przepraszającą ${ }^{82}$. Tyle że diariusz konwokacji senatu z APP, który zawiera tekst przeprosin nie ma dokładnej daty ${ }^{83}$. Albo więc działacz rokoszowy został na moment zwolniony z więzienia wawelskiego i do niego powrócił, albo tekst dotyczy roku 1609, gdy Herburt w lutym został wypuszczony na wolność.

W dniu 27 czerwca $^{84}$ lub, jak chcą niektórzy, 14 czerwca przepraszał króla S. Cikowski. Przedstawił się jako osoba umiarkowana, ,,abym mógł animusze ludzkie od pociągów tych do których przyszło odwieść a raczej do miełej zgody przywieść i do uspokojenia prawdziwego i trwałego panowania W.K.M.”. Tym duchem pobudzony ruszył pod Warszawę w 1607 i został delegatem rokoszowym. „A jakom do wypowiedzenia posłuszeństwa WKM ani rady, ani contemptu swego nie dawałem, tak i podpisować na nię i sam nie chciałem i ludzi szlacheckich osób do sześćdziesiąt kilku ze mną będących od podpisu odwiodłem, zaczym i w szyku pod Guzowem przeciw WKM nie stawałem". Prosił zatem pokornie króla o przebaczenie.

W. Urbaniak stwierdza, że konwokacja zakończyła obrady około 20 czerwca $^{85}$. Można jednak tę datę doprecyzować. Otóż w diariuszu z APP jest informacja, że obradowano w dniu 25 czerwca - wówczas przepraszał króla Piotr Łaszcz, a ponadto dwa dni później czynił to Stanisław Cikowski ${ }^{86}$. Tak więc narady zakończono zapewne 27 czerwca, w piątek.

Z pewnością ważnym osiągnięciem konwokacji był uniwersał królewski z dnia 9 czerwca, podpisany przez senatorów, łącznie z wojewodą krakowskim. Król przedstawia się w nim jako monarcha pragnący pokoju, zgody w państwie i miłujący wolności. Przez dwa lata „przez te wszystkie zamieszanie RP żałośne czasy”, nawet „gdy gwałt to na nas wycisnął, że nam ostrze srzodki przed się brać przyszło i nie skwapieliśmy się na surowość prawa pospolitego, szanowaliśmy Narodu tego zacnego różnym mniemaniom uwiedzione. Łaskawość i dobrotliwość naszą pokazali i uniwersałami oświadczyli, cierpliwie czekając i ojcowskim affectem do zgody wszystkich wzywając”. A ,po takich declaratiach przez któreśmy oświadczyli przychylność naszą wszytkim, którzy się byli w tym zaciągu zawiedli, drogę do łaski

Ibidem, s. 5004, 5005.

81 W. Urbaniak, op. cit., s. 138.

82 H. Schmitt, op. cit., s. 583-585.

83 APP 31, t. II, s. 469-472.

84 BN III 3087, s. 5006; APP 31, t. II, s. 448-451.

85 W. Urbaniak, op. cit., s. 139.

${ }^{86}$ APP 31, t. II, s. 445, 448. 
naszej, gdyby jej szukać chcieli”. Król, chcąc uspokojenia państwa w obliczu zagrożenia zewnętrznego, zwołał do siebie senatorów. „Że gdy się tu do nas stawił Wielmożny Mikołaj Zebrzydowski, Wojewoda Krak. i przez środki, które mu od PP. Senatorów podane były, posłuszeństwo nam wypowiedziane przyznawszy i przeszłych swych zaciągów odstąpiwszy wiarę nam swą oświadczył i łaski naszej szukał”. Przeto król odłożył swe urazy na stronę i mu przebaczył. Monarcha chce też, aby przyjęci do łaski lub jej chcący, spokojnie się zachowywali, „ojczyzny rozruchem swym nie trudnili”. Jeśli potrzebują naprawy praw, niech spokojnie do sejmu czekają. Jednak jeśli ktoś pogardzi łaską królewską, na tego mają, jako na gwałtownika, uderzyć starostowie i urzędnicy wojenni ${ }^{87}$.

W podsumowaniu autor chce podkreślić dwie kwestie. Po pierwsze, konwokacja senatu spełniła swe podstawowe zadanie. Została bowiem zwołana, aby zapewnić uspokojenie sytuacji wewnętrznej Rzeczypospolitej i przywrócić ostatecznie ład ustrojowy państwa. W rezultacie Mikołaj Zebrzydowski i wielu czołowych przywódców rokoszowych przeprosiło króla, co zadecydowało nie tylko o uspokojeniu rozkołysanych nastrojów, ale i o zwycięstwie moralnym Zygmunta III, któremu przepraszający byli zmuszeni przyznać rację. Doprowadzono ponadto do zawarcia ugody między Januszem Radziwiłłem a hetmanem litewskim Janem Karolem Chodkiewiczem. Nie udało się natomiast spacyfikować konfliktu pomiędzy starostą leżajskim Opalińskim a Diabłem Stadnickim. Doprowadził on do wojny domowej i śmierci Diabła w 1610 roku.

Druga kwestia to obraz konwokacji we współczesnych źródłach. Tylko w diariuszu w Bibliotece Czartoryskich 341 jest zawarty systematyczny opis czynności podejmowanych na forum konwokacji, łącznie z kwestiami bezpieczeństwa zewnętrznego i stosunków z sąsiadami. W innych diariuszach przedstawiona została przede wszystkim kwestia przeprosin króla przez Mikołaja Zebrzydowskiego i na ogół także przez Zygmunta Grudzińskiego. Są też z reguły materiały dotyczące godzenia Janusza Radziwiłła z Janem Karolem Chodkiewiczem. Natomiast przeprosiny w wykonaniu mniej znaczących przywódców rokoszowych były odnotowywane często z różnymi datami i w żadnym diariuszu nie było kompletu tych wystąpień. Widać więc wyraźnie, że współcześni nie przywiązywali do tego większej uwagi.

\section{Bibliografia}

Dubas-Urwanowicz E., O nowy kształt Rzeczypospolitej. Kryzys polityczny w państwie w latach 1576-1586, Warszawa 2013.

Kempa T., Postawa kasztelana krakowskiego Janusza Ostrogskiego w okresie rokoszu Zebrzydowskiego, w: Wobec króla i Rzeczpospolitej. Magnateria w XVI-XVIII wieku, red. E. Dubas-Urwanowicz, J. Urwanowicz, Kraków 2012, s. 267-296.

Kieniewicz L., Senat za Stefana Batorego, Warszawa 2000.

Lewandowska-Malec I., Vicarius regis. Rola arcybiskupa gnieźnieńskiego pod nieobecność króla elekcyjnego, w: Krakowskie studia z historii państwa i prawa, t. 3, red. W. Uruszczak, D. Malec, M. Mikuła, Kraków 2010, s. 89-98.

Maciszewski J., Wojna domowa w Polsce (1606-1609). Część I. Od Stężycy do Janowca, Wrocław 1960.

87 B. Czart. 337, s. 701, 702, 703. 
Maciszewski J., Próby mediacyjne Piotra Tylickiego w dobie rokoszu sandomierskiego (16061608), w: Kościót w Małopolsce, red. W. Kowalski, J. Muszyńska, Kielce 2001, s. 321-330.

Opaliński E., Zjazd rokoszowy warszawski w październiku 1607 r., „Kwartalnik Historyczny”, $121 / 2004$, nr 3, s. 521-539.

Rzońca J., Sejmy z lat 1597 i 1598 . Czesść I. Bezowocny sejm z 1597 roku, Warszawa-Wrocław 1989.

Schmitt H., Rokosz Zebrzydowskiego, Lwów 1858.

Strzelecki A., Sejm z roku 1605, Kraków 1921.

Urbaniak W., Zamoyszczycy bez Zamoyskiego. Studium dekompozycji ugrupowania politycznego, Warszawa 1995.

\section{Źródła drukowane}

Łubieński S., Droga do Szwecji Zygmunta III, króla polskiego i szwedzkiego, w 1593 roku, Rozruchy domowe $w$ Polsce $w$ latach 1606-1608, wyd. J. Byliński, W. Kaczorowski, Opole 2009.

\section{Archiwalia}

Biblioteka Czartoryskich 337, 339, 341, 1630, 1639. Teki Naruszewicza 103, 104.

Biblioteka Narodowa: BN III 3087.

Biblioteka PAU/PAN 1048.

Biblioteka Raczyńskich 18.

Archiwum Główne Akt dawnych: APP 31, t. II.

Riksarkivet Stockholm, Extranea IX Polen, vol. 103, 115. 